\title{
Christiaan Barnard (1922-2001): First heart transplant surgeon
}

\author{
Siang Yong $\underline{\operatorname{Tan}}^{1}$, MD, JD, Katy Linskey ${ }^{2}$
}

I n 1967, an obscure cardiac surgeon in South Africa became an instant household name and the name Christiaan Barnard was indelibly linked to a feat once thought impossible - transplanting the human heart.

PATH TO MEDICINE Christiaan Neethling Barnard was born on 8 November 1922 in a small town called Beaufort West in South Africa. Many have speculated that his decision to pursue a medical career, particularly one in cardiac surgery, was motivated by the death of his five-year-old brother Abraham from heart disease. However, Barnard later said that his initial attraction to medicine was his desire to make money. He graduated in 1946 from the University of Cape Town Medical School, placing near the middle of the class. After an internship at Groote Schuur Hospital in Cape Town, he worked as a general practitioner in the rural town of Ceres. In 1948, he married a nurse at Groote Schuur, Aletta Louw. A few years later in 1951, Barnard took a junior medical post at City Hospital, then won a scholarship for postgraduate training in cardiothoracic surgery at the University of Minnesota in the United States (US). There, he learnt to surgically correct congenital heart defects. In

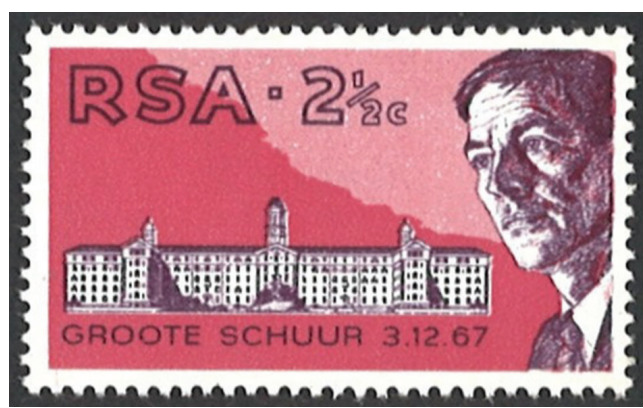

earnest. In 1958, Dr Norman Shumway and Dr Richard Lower of Stanford University experimented with cardiac transplantation techniques in dogs and studied tissue rejection. At an American College of Surgeons' convention in October 1967, Dr Lower's film of a transplanted canine heart with over 15 months' survival prompted Dr Shumway to declare that the time had come for clinical application. South Africa raced to become the first in line.

FIRST HEART TRANSPLANT For his first attempt at a heart transplant, Barnard selected as the recipient Louis Washkansky, a 54-year-old grocer with severe coronary artery disease. A diabetic with peripheral vascular disease, his leg oedema was so severe that it required drainage with subcutaneous needles. A first possible black donor was passed over because Barnard wanted to avoid international criticism of South Africa's apartheid policies. Then on 2 December 1967, opportunity came with the tragedy of 25-year-old Denise Darvall, who was struck by an automobile while crossing a Cape Town street and sustained severe brain damage and brain death. Barnard's transplant team gained permission from Darvall's father to use her heart. The entire procedure took nine hours and 1958, armed with a heart-lung machine provided by the US government, Barnard returned to Cape Town to establish Groote Schuur Hospital's first heart unit and soon headed its Division of Cardiothoracic Surgery.

TRANSPLANTATION MOMENTUM In 1964, Barnard began working with canine renal transplants, spending three months with renal transplant surgeon David Hume at the Medical College of Virginia in the US. Upon his return to Cape Town, he successfully performed South Africa's first kidney transplant in 1967 . He also began experimenting with canine heart transplants with the help of gifted laboratory technician Hamilton Naki, a black South African.

Near the end of the 19th century, famed British physician Sir James Paget was quoted as saying: "Surgery of the heart has probably reached the limits set by nature to all surgery, and no new discovery can overcome the natural difficulties that attend a wound of the heart." Yet, less than a century later, pioneering research in heart transplant surgery had begun in involved a team of 30 professionals. The recipient patient only lived 18 days with his new heart, succumbing to pneumonia while on a hefty immunosuppressive regimen. His short survival prompted doubts about the true value of the procedure. Critics felt that Barnard did not deserve the instant acclaim when Dr Shumway and others had done the bulk of the background research, and more qualified transplant teams were held back not by their lack of surgical skill but legal and ethical hurdles.

CELEBRITY STATUS Barnard became an overnight international celebrity. A New York Times article captured public sentiment with these words: "The world was startled to learn that the human heart, traditional seat of the emotions, home of the soul, symbol of love and of St Valentine's Day, could be transplanted from one person to another as though it were nothing more than a complicated piece of plumbing." Barnard's picture graced the covers of magazines such as Time, and he accepted invitations worldwide to meet dignitaries and heads of states. In public, he was mobbed for autographs, and the press loved him

${ }^{1}$ Emeritus Professor of Medicine, University of Hawaii, ${ }^{2}$ Research carried out during senior medical clerkship at the John A Burns School of Medicine, University of Hawaii, Honolulu, HI, USA

Correspondence: Prof Tan Siang Yong, 2226 Liliha Street, Suite B-104, Honolulu, HI 96817, USA. siang@hawaii.edu 
for his good looks and his witty, articulate manner of speaking. Barnard thrived on the attention, saying "Any man who says he doesn't like applause and recognition is either a fool or a liar". In 1969, he published his autobiography, entitled One Life.

Derided for his "rather impetuous, flamboyant and undignified global lap of honour", Barnard himself admitted that his open indulgence in women and socialising did not match the image of a distinguished professor. He gained notoriety for his love affairs, notably with the famous Italian actress Gina Lollobrigida. He divorced his first wife in 1969 and a year later married Barbara Zoellner, a multimillionaire's 19-year-old daughter. After divorcing her in 1981, he remarried, for a third time, 23-year-old fashion model Karin Setzkorn. That, too, ended in a divorce in 2000. One of his colleagues summed up Barnard's complex character in these words: "He was then, at once, rough-at-theedges poor boy and charming sophisticate, democrat and tyrant, selfless healer and boorish egotist, lover and Don Juan, shrewd parvenu and naive acceptor of glitterati adulation - but, above all, surgical visionary and simply the most unforgettable character of the second generation of cardiac surgeons."

MORE HEART TRANSPLANTS Barnard's next transplant candidate was 59-year-old dentist Philip Blaiberg. He modified the surgical technique and added antilymphocyte serum to the post-transplant immunosuppressive regimen. Blaiberg lived for 19 months after his transplant, and as a testament to his return to normal life, the media disseminated photos of him bathing contentedly in the ocean. However, Blaiberg's daughter asserted after his death, "My father's life was hell after the transplant. He suffered terribly all the time, but the world was cheering for a medical miracle and did not know."

Barnard continued to perform transplants, but only ten were done in the following five years, with mixed results. He then took on heterotopic transplantation, where only the diseased portion of the recipient's heart was removed. He performed some 49 procedures over a nine-year period, but the results were uninspiring. It was not until the advent of cyclosporine in the 1980s that orthotopic cardiac transplantation was revitalised. Heart transplant recipients today enjoy a one-year survival rate of over $80 \%$ and five-year survival of about $70 \%$.

THE SECOND LIFE While the great surgeon's hands were what brought him fame, they failed him in the end. Rheumatoid arthritis had plagued Barnard his entire adult life, and involvement of the hands forced his early retirement in 1983. He subsequently pursued other ventures and helped to establish a new transplant institute during his two years at the Baptist Medical
Center in Oklahoma City in Oklahoma, US. His prodigious writing attracted a limited readership, including another autobiography called The Second Life, as well as various novels and health books such as Christiaan Barnard's Program for Living with Arthritis. He also served as research adviser to the Clinique la Prairie in Switzerland and claimed that the cosmetic Glycel had the ability to cause rejuvenation of cells. The controversial product was later denied approval by the US Food and Drug Administration, and this dubious venture, along with appearances in television commercials and sponsorship of commercial products, tarnished his reputation as a serious scientist and surgeon.

Barnard especially loved his paediatric patients and established the Christiaan Barnard Foundation to benefit underprivileged children worldwide. In his book, he wrote: "What I would like to be remembered for is not for doing the first heart transplant in the world. I would like to be remembered for the children I have treated for a variety of abnormal heart diseases.... There was a little girl whom I went to see the day before her operation. I asked her, 'My darling, what is wrong with you?' She said, 'I have got a broken heart.' When we mended her heart, that gave me the utmost satisfaction."

In addition to his disabling arthritis, Barnard also suffered from asthma, once remarking that he greatly feared dying from an asthmatic attack. He carried an inhaler with him at all times. In 2001, when travelling in the coastal city of Paphos, Cyprus, he suffered an acute asthmatic attack that killed him at the age of 78 .

\section{BIBLIOGRAPHY}

- Altman LK. Christiaan Barnard, 78, surgeon for first heart transplant, dies. The New York Times 2001 Sep 3; Sect A: 1.

- Barnard C. One Life. 1st ed. Toronto: The Macmillan Company, 1969.

- Brink JG, Cooper DK. Heart transplantation: the contributions of Christiaan Barnard and the University of Cape Town/Groote Schuur Hospital. World J Surg 2005; 29:953-61.

- Cheng TO. Hamilton Naki and Christiaan Barnard versus Vivien Thomas and Alfred Blalock: similarities and dissimilarities. Am J Cardiol 2006; 97:435-6.

- Cooper DK. Christiaan Barnard and his contributions to heart transplantation. J Heart Lung Transplant 2001; 20:599-610.

- Davies MK, Hollman A. Christiaan Neethling Barnard (1922-). Heart 1997; 77:406.

- Hoffenberg R. Christiaan Barnard: his first transplants and their impact on concepts of death. BMJ 2001; 323:1478-80.

- Judd T. Christiaan Barnard, celebrated pioneer of heart transplant surgery, dies aged 78. The Independent 2001.

- Massad MG. Christiaan Neethling Barnard (1922-2001). J Thorac Cardiovasc Surg 2002; 123:1-2.

- Ram N. A celebrity of world medicine: interview with Dr Christiaan Barnard. In: Frontline: India's National Magazine [online] 1997. Available at: https://frontline. thehindu.com/static/html/fl1421/14210890.htm. Accessed September 20, 2019.

- Rowe DJ. Dr. Christiaan Barnard: renowned surgeon, egoist but an old-fashioned family doctor at heart. Interview by Robert MacNeil. Can Med Assoc J 1979; 120:98-9.

- Tresniowski A. King of Hearts. In: People magazine [online] 2001. Available at: https://people.com/archive/king-of-hearts-vol-56-no-12. Accessed September 20, 2019. 